\title{
Quality Evaluation Of Some Softening Agents Used In The South East, Nigeria
}

\author{
Nkeiruka M. Oly-Alawuba \\ Department of Nutrition and Dietetics, College of Health Sciences, \\ Imo State University, Owerri, 23483, Nigeria. \\ Ngozika C. Okechukwu-Ezike \\ Department of food science and technology, \\ Imo State University, Owerri.
}

\begin{abstract}
Mineral composition and the Sensory attributes of Some food softening agents: Potash, dry Plantain leaf, Unripe Plantain peel, dry Palm bunch (Extracts) and their effects on African bread fruit were evaluated. The results showed the following mineral contents of the samples: Phosphorus - 15.66mg/100g (Potash) to $26.22 \mathrm{mg} / 100 \mathrm{~g}$ (Palm bunch); Iron - 2.78ppm (Palm bunch) to $6.77 \mathrm{mg} / 100 \mathrm{~g}$ (Plantain peel); Zinc contents of the samples ranged from 2.25ppm (Plantain peel) to $3.34 \mathrm{ppm}$ (Potash); Potassium content of the samples ranged from $27.81 \mathrm{mg} / 100 \mathrm{~g}$ (Palm bunch) to $176 \mathrm{mg} / 100 \mathrm{~g}$ (Potash); Sodium content ranged from $9.17 \mathrm{mg} / 100 \mathrm{~g}$ (Palm bunch) to $24.78 \mathrm{mg} / 100 \mathrm{~g}$ (Potash); Magnesium ranged from $11.86 \mathrm{mg} / 100 \mathrm{~g}$ (Plantain peel) to $13.44 \mathrm{mg} / 100 \mathrm{~g}$ (Potash, Plantain leaf); Lead ranged from $0.17 \mathrm{mg} / 100 \mathrm{~g}$ (Palm bunch) to $0.39 \mathrm{mg} / 100 \mathrm{~g}$ (Potash).Calcium content of the softening agents ranged from $14.69 \mathrm{mg} / 100 \mathrm{~g}$ (Palm bunch) to $27.82 \mathrm{mg} / \mathbf{1 0 0 g}$ (Potash). Sensory parameters of the samples evaluated were taste, colour, aroma, texture and general acceptability. The mean taste scores of the samples ranged from 4.44 (Palm bunch extract) to 6.72 (Potash), mean colour scores ranged from 4.04 (Palm bunch extract) to 6.44 (Potash extract), mean aroma scores ranged from 4.04 (Palm bunch extract) to 6.08 (Plantain peel). Texture of the samples ranged from 8.1 (Plantain peel, Plantain leaf extracts) to 8.4 (Palm bunch extract). The general acceptability of the samples ranged from 7.20 (Palm bunch, Potash extracts) to 7.5, (plantain peels extracts).The plantain peel extract had the highest mean sensory scores in terms of overall acceptability. Its effects as a softening agent were similar to those of the potash which served as a control sample.
\end{abstract}

Keywords: Palm bunch, Unripe Plantain peel, Potash, Softening agents

\section{INTRODUCTION}

Plantain is a crop from the genus Musa. Its fruits are edible, and are generally cooked for consumption. This is different from the soft and sweet banana (which is often called dessert banana). Globally, plantain constitute fourth most important commodity after rice, wheat and maize. Over 130 countries including Nigeria and South-Africa grow plantain as a stable food. The way certain species are called, shows how they are been used: cooking plantain, banana plantain, beer banana, bocadilo plantain (the little one), etc. over the years, plantain has further been converted into snacks that is consumed and loved by many known as "plantain chips", of which is fried salted for consumers delight. All members of the genus Musa are indigenous to the tropical region of Southeast Asia, firmer than dessert bananas; they also have less sugar. Dessert bananas are often eaten raw; plantains are usually cooked or otherwise processed before they are eaten. Plantains are staple foods in tropical regions, treated similarly to potatoes. They also have similar taste.Plantain leaf is a large long brood leaf of the crop plantain. It is green in colour and has visible parallel lines running by each side of the leaf. It is divided by a semi hard long stick. Some has brood leaves, while some have short leaves. The 
leaves are of many health benefits, and can be used as herbs in concoction for bite reliefs, burns, a cover for locally fermented foods like wario, ugba, usu etc. it also serves as food for life stock. According to Eleritch,(2013) plantain is rich in potassium and chlorophyll. Plantain leaves have a wide range of applications because they are large, flexible, waterproof and decorative. They are used for cooking, wrapping and food-serving in a wide range of cousins in tropical and subtropical areas. They impart aroma to food that is cooked in or served in them; steaming with plantain leaves imparts a subtle sweet flavor and aroma to the dish. Plantain peel is the thick green cover protecting a plantain seed. It is strong when green and soft when cooked. It releases a sticky liquid when punctured or cut open. It is presently been consumed as food in some parts of the country. It also serves as food for livestock. It is a source of dietary fiber and antioxidant compound. According to Ploetz, et al.,(2007) In green color, (unripe stage) plantain peels which contain $40 \%$ starch is transformed into sugars after ripening, with about $15 \%$ starch and $30 \%$ free sugars. It can also be used in the production of local soups. Palm bunch is a fruit holder of the palm tree. It is a large oval shaped structure which weights up to $45 \mathrm{~kg}$. it is seen in any matured palm tree as it carries the palm fruit (over hundreds and thousands of them). It is fairly brown in color and has sharp thorns all over it. it is a rich source of potassium Alimon and Wan,(2004). Its ash is used to make local soap, the liquid, to coagulate red oil and also serves as a healthy softening agents. It is good organic manure because it is rich source of potassium.Potash also known as "akanwu" in Igbo land, it is a type of lake salt. Potash is dry and dehydrated in nature. This type of lake salt usually shoots out from the soil during the rainy season, but tends to fall off, solidifies and gets dries during the dry season. It is used in the coagulation of red oil and also serves as a softening agent for legumes and bread fruit (ukwa) (Quick guide to potash,2013).

Plantain peels and palm bunch are regarded as wastes which must be discarded or used as animal feed and manure. There are little or no information on their applications in food. Little is known traditionally about their applications as softening agents in foods. There are no industrial applications either. The exact quantities are not documented. Discarding these food materials equals losses of micro nutrient, thus huge losses of materials that could be of great nutritional and health benefits.

There is therefore the need to enhance the knowledge of the people in order to enable them improve their nutrition, thus their health; especially in the rural and sub-urban communities where much of such softening agents are used in food preparations. Value is added to these aspects of produce which ordinarily are often thrown away as waste or just used as animal feed. The data obtained could serve as useful tool in their production on a larger scale for industrial food applications.

\section{MATERIALS AND METHODS}

Dry plantain leaves, plantain peels (green) and palm bunch were obtained from Aboha Ohii and the Potash from the local market, all in Owerri West Local Government Area in Imo State. The palm bunch, dry leaves and peels of the plantain crop were separately burnt to ashes .Twenty $(20 \mathrm{~g})$ of each ash was thoroughly mixed $1060 \mathrm{~g}$ of water and sieved through a clean muslin cloth to extract the softening agent. The cake was discarded while the filtrate was stored in a clean air tight container for further analysis and other uses. The potash was not burnt but crushed, mixed with water in same ratios and sieved.

Twelve (12) cups of the African breadfruit was washed severally in clean water to ensure thorough removal of sand and dirts. These were divided into four (4) equal parts of Three (3) cups each. The 4 different softening extracts were each $(60 \mathrm{ml})$ added to separate sets of the 
African breadfruit in medium sized pots and set on fire to boil and cook. After $15 \mathrm{~min}$, the breadfruits were all softened and cooked. The food was slightly seasoned by the addition of $1 / 2$ tsp of salt and $1 / 2$ tsp of black dried pepper to each of the pots. They were dished into 4 different labeled clean bowls, from which they were served separately to the panelist(25) for sensory evaluation, using the nine point hedonic scale described by Ihekoronye and Ngoddy,(1985) .
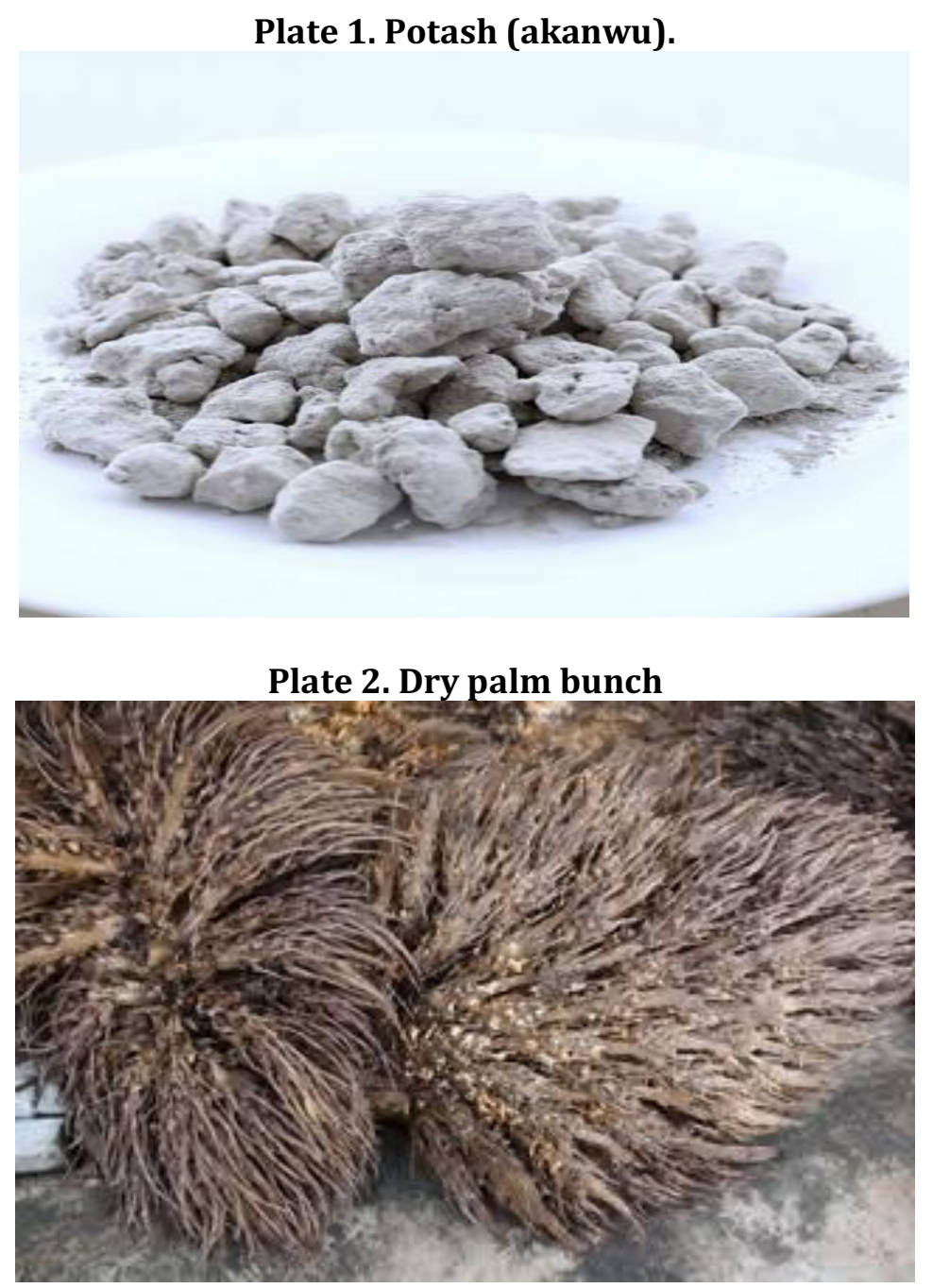

Plate 3. Palm Bunch Ash

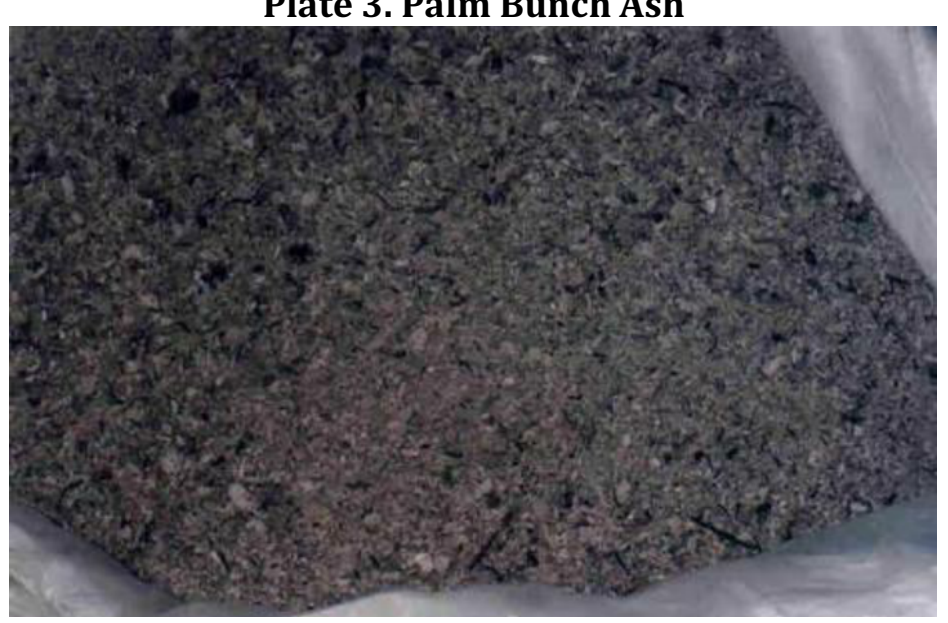




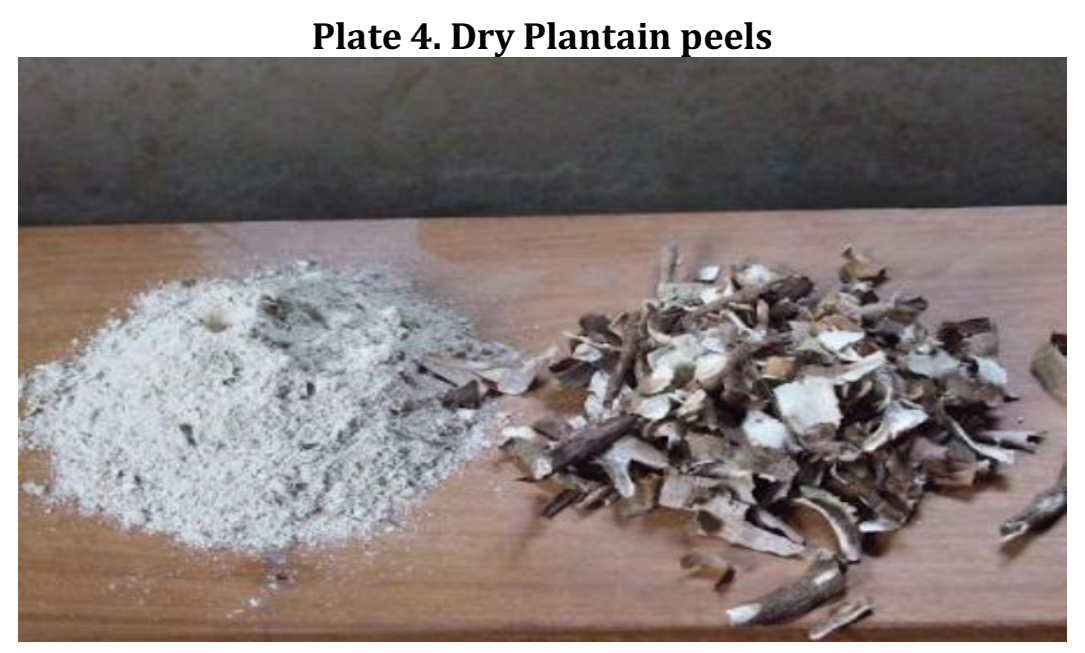

\section{Plate 5 Plantain peel ash}

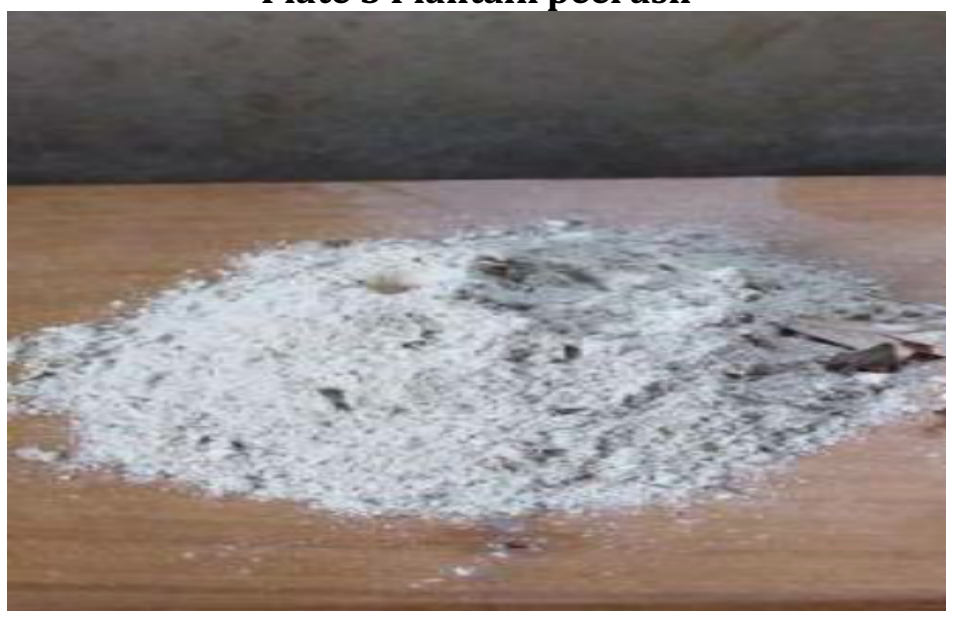

Plate 6. Dry Plantain leaf

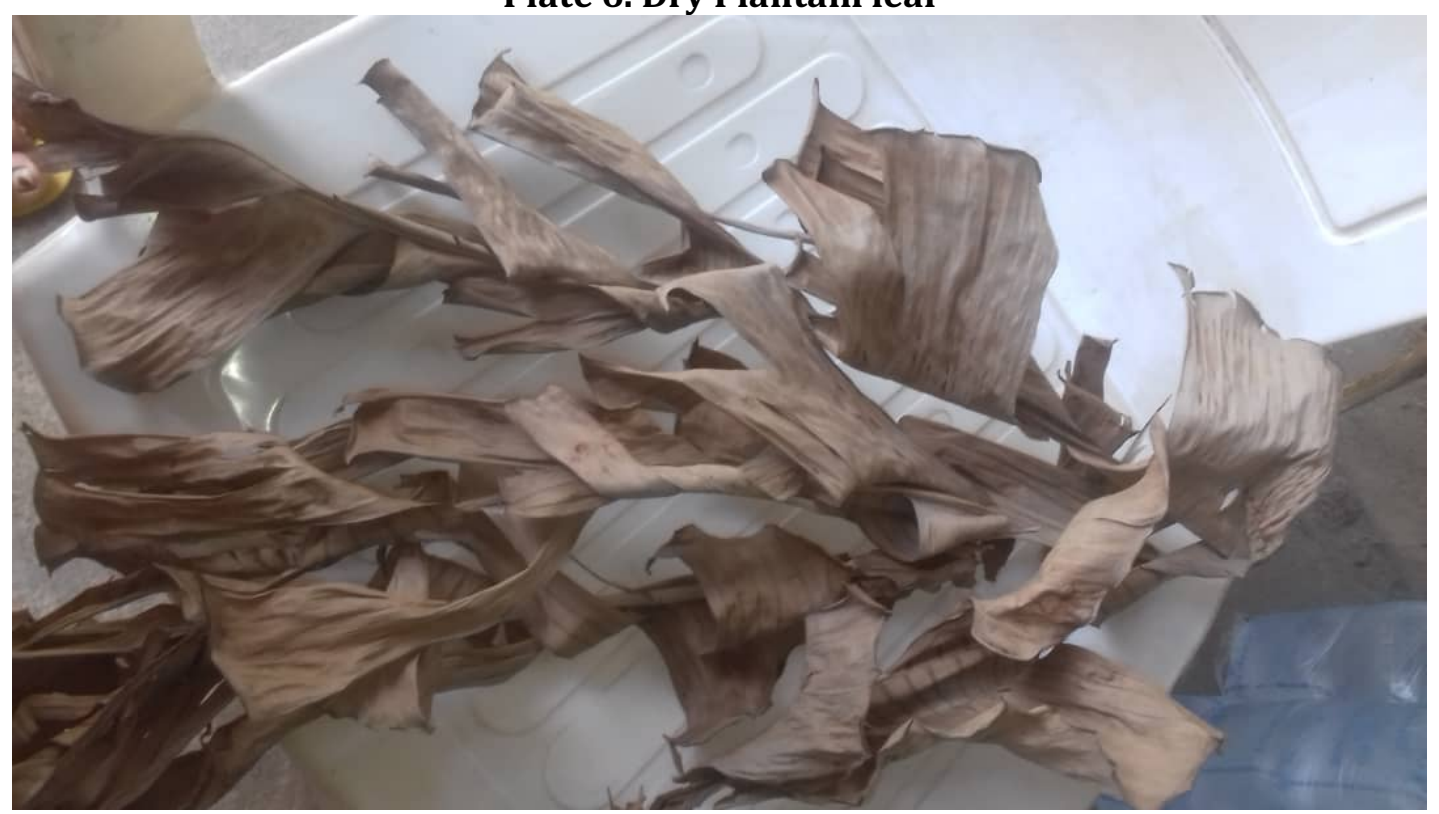




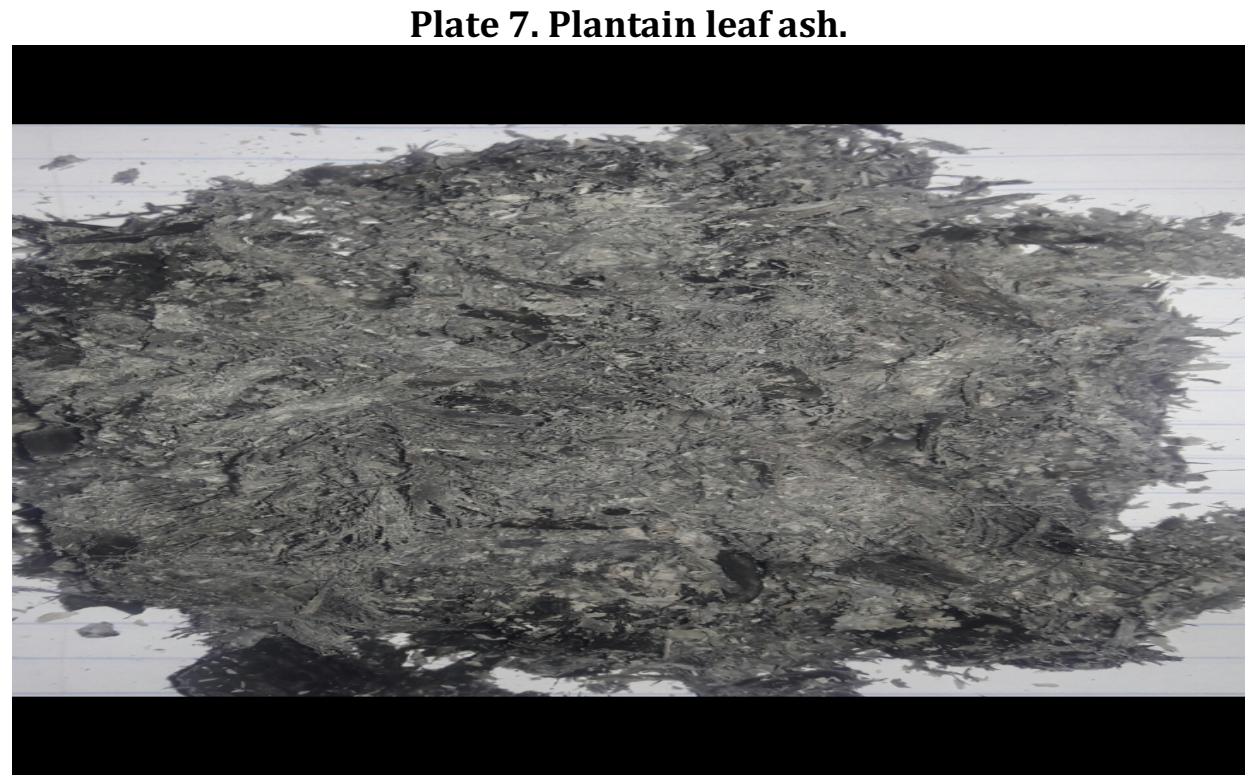

\section{Mineral Analysis.}

Phosphorus in the samples was determined by the Vanado-mohybdate (yellow) spectrometry as described by AOAC (2000); SODIUM AND POTASSIUM BY FLAME PHOTOMETRY method described by AOAC (2000); IRON by The method of AOAC (2000).Calcium and Magnesuim contents of the test sample were determined by the EDTA (Ethylenediamine Tetra Acetic Acid). Complexiometric titration of AOAC (2000).The heavy metals, lead and zinc were determined in the softening agents by acid digestion. The ashed softening agents in powdered form were dissolved in concentrated nitric acid with $25 \mathrm{ml}$ de-ionized water). Heavy metalss were determined using an atomic absorption spectrometer.

\section{Sensory Evaluation.}

Sensory evaluation was carried out using twenty five panelists who were regular consumers of African bread fruit and were not allergic to any softening agesnt or the food. Samples were scored for taste, colour, aroma, texture/mouth feel and overall acceptability on a 9-point hedonic scale with 1 representing dislike extremely, 5 - neither like nor dislike and 9 - like extremely (Ihekoronye and Ngoddy, 1985).

The data collected were subjected to analysis of variance (ANOVA). Means were separated using Duncan's new multiple range taste (DNMRT) using the Statistical Package for the Social Sciences (SPSS) version 20.0 (SPSS Inc. Chicago 11, US.

\section{Mineral Composition Of Four Food Softening Agents}

\section{RESULTS AND DISCUSSION}

Mineral compositions of the food softening agents were presented in Table 1 below. The minerals evaluated were Phosphorus, Iron, Zinc, Potassium, Sodium, Magnesium, Lead and Calcium.

Table 1: Mineral Composition of Food Softening Agents

\begin{tabular}{|c|c|c|c|c|c|c|c|c|}
\hline $\begin{array}{l}\text { Parameter } \\
\text { Samples }\end{array}$ & $\begin{array}{l}\text { Phosphorus } \\
\text { (mg/100g) }\end{array}$ & Iron (Ppm) & $\begin{array}{l}\text { Zinc } \\
\text { (Ppm) }\end{array}$ & $\begin{array}{l}\text { Potassium } \\
\text { (mg/100g) }\end{array}$ & $\begin{array}{l}\text { Sodium } \\
\text { (mg/100g) }\end{array}$ & $\begin{array}{l}\text { Magnesium } \\
(\mathrm{mg} / \mathbf{1 0 0 g})\end{array}$ & $\begin{array}{l}\text { Lead } \\
(\mathrm{mg} / 100 \mathrm{~g})\end{array}$ & $\begin{array}{l}\text { Calcium } \\
(\mathrm{mg} / \mathbf{1 0 0 g})\end{array}$ \\
\hline Palm Bunch & $26.22 \pm 0.11^{b}$ & $2.78 \pm$ & $3.18 \pm 0.02$ & $27.81 \pm 0.55^{\mathrm{d}}$ & $9.17 \pm 0.01^{\mathrm{d}}$ & $12.58 \pm 0.17 b$ & $0.17 \pm 0.14^{c}$ & $14.69 \pm 0.12^{\mathrm{d}}$ \\
\hline Plantainpee & $119.44 \pm 0.02^{c}$ & $6.77 \pm 0.04^{\mathrm{a}}$ & $2.25 \pm 0.14$ & $36.61 \pm 2.70^{b}$ & $18.29 \pm 0.14$ & b $11.86 \pm 0.05^{c}$ & $0.25 \pm 0.01^{b}$ & $23.52 \pm 0.11^{b}$ \\
\hline Potash & $15.66 \pm 0.06^{d}$ & $3.82 \pm 0.00^{c}$ & $3.34 \pm 0.85$ & $176.0 \pm 0.01^{a}$ & $24.78 \pm 0.03$ & $13.44 \pm 0.22^{a}$ & $0.39 \pm 0.01^{\mathrm{a}}$ & $27.82 \pm 0.28$ \\
\hline $\begin{array}{l}\text { Plantain } \\
\text { Leaf }\end{array}$ & $29.51 \pm 0.16^{a}$ & $4.68 \pm 0.10^{b}$ & $2.88 \pm 0.03$ & $=32.83 \pm 0.09$ & $13.72 \pm 0.10$ & $13.44 \pm 0.72^{\mathrm{a}}$ & $0.18 \pm 0.00^{c}$ & $=21.95 \pm 0.17 \mathrm{c}$ \\
\hline LSD & 0.04 & 0.03 & 0.02 & 0.03 & 0.22 & 0.00 & 0.04 & 0.27 \\
\hline
\end{tabular}

Mean Values with different superscripts along the same column are significantly ( $\mathrm{p} \leq 0.05)$ different. 
Phosphorus contents of the samples were $26.22 \mathrm{mg} / 100 \mathrm{~g}$ for palm bunch; $19.44 \mathrm{mg} / 100 \mathrm{~g}$ for plantain peels; $15.66 \mathrm{mg} / 100 \mathrm{~g}$ for potash and $29.51 \mathrm{mg} / 100 \mathrm{~g}$ for plantain leaf. Plantain leaf had the highest significant $(\mathrm{p} \leq 0.05)$ phosphorus content among the samples. According to Olusanya,(2008).,Plantain and banana are rich in Potassium, Sodium, chlorine, phosphorus and magnesium. They are fair sources of Calcium, Iron, Manganese and Mulphur, but with traces of Cooper, Iodine, Zinc and Cobalt. This showed that plantain leaf could be a potential source of phosphorus. Iron contents of the softening agents were $2.78 \mathrm{ppm}$ for palm bunch to $6.77 \mathrm{ppm}$ for the plantain peel. The iron content of the four different softening agents was highest in the plantain peels with the values of $6.77 \mathrm{ppm},(\mathrm{P} \leq 0.05)$ which was significantly higher than the values obtained in the other ash sample. The high value of iron in the peels could be the attributed high concentration of the irons in the plantain fingers, which the peels covered. Iron from food sources such as plantain when absorbed in the body is found in the hemoglobin of the erythrocytes. It assists in the transport of oxygen from the lungs to the other tissues in the body Olawoley,(2000).

Zinc contents of the softening agents analyzed were $3.18 \mathrm{mg} / 100 \mathrm{~g}$ for the palm bunch, $2.25 \mathrm{mg} / 100 \mathrm{~g}$ for the plantain peels, $3.34 \mathrm{ppm}$ for the potash and $2.88 \mathrm{ppm}$ for the plantain leaf. The Zinc content of the samples was highest in the of potash softening agent. Also zinc is one of the trace elements needed by human beings. The human body contains a total of about $2 \mathrm{~g}$ of zinc mainly in the hair, bones, eyes and male sex glands and secretions. It helps in lipid, protein carbohydrate and nucleic acid metabolism. Its deficiency has been found to lead to growth retardation, male hypoganadism, delayed wound healing and poor appetite. Also zinc deficiency has also been found to impair good development of the sense of taste. Other food sources of Zinc are meats poultry sea foods, eggs, cheese, milk and peanut butter Olusanya,(2008)

Potassium content of the samples ranged from $27.81 \mathrm{mg} / 100 \mathrm{~g}$ for sample of palm bunch to $177 \mathrm{mg} / 100 \mathrm{~g}$ for potash. Potash (akanwu) is a type of lake salt(sodium carbonate) that is dry and hydrated in nature. Potassium helps to maintain osmotic pressure and the acid based balance of the body. It also helps to activate several enzyme reactions potash is recommended in cooking of beans, akidi (black Mexican beans) and cowpea beans which assists in tenderization of the pulses so easily and supplies the body with potassium. The potash potassium content was significantly $(p \leq 0.05)$ higher than its contents in other samples plantain peels had the next significant value of potassium.

Sodium content of the samples analyzed ranged from $9.17 \mathrm{mg} / 100 \mathrm{~g}$ for the palm bunch to $24.78 \mathrm{mg} / 100 \mathrm{~g}$. The potash had the highest amount of Sodium, compared to the palm bunch. The sodium in potash used in preparation of local delicacies/dishes has the potential to regulate the acid-base balance of the body. The other sources of sodium is common salt and drinking water.

Magnesium content of the softening agents ranged from $11.86 \mathrm{mg} / 100 \mathrm{~g}$ for plantain peel to $13.44 \mathrm{mg} / 100$ for samples. The magnesium values of potash and plantain leaf were equivalently and significantly $(\mathrm{p} \leq 0.05)$ higher than those of the rest samples. Magnesium plays a key role as an essential ion in many fundamental enzymatic reactions in intermediary metabolism. Consequently, all human tissues contain small amounts of magnesium. Also some excellent sources of magnesium are leafy green vegetables, nuts and soybean and snails Adewale,(2008). 
Lead is a food contaminant. It is a naturally occurring bluish-gray metal found in small amounts in the earth. It has no special taste or smell and can be found in all parts of our environment due to human activities (Ibeawuchi et.al.2006, ). The lead content of the samples were $0.17 \mathrm{mg} / 100$ for palm bunch, $0.25 \mathrm{mg} / 100 \mathrm{~g}$ for plantain peels, $0.39 \mathrm{mg} / 100 \mathrm{~g}$ for potash and $0.85 \mathrm{mg} / 100 \mathrm{~g}$ for plantain leaf. The lead content was highest in potash which could be attributed to environment, factors and the soil where it was found and grown. Also according to Diane,(2004) human activities such as mining, manufacturing and the burning of fossil fuels are the major sources of environmental lead found in most food materials such as potash and tubers gotten from soil. Calcium content of the sample were $14.69 \mathrm{mg} / 100 \mathrm{~g}$ for sample palm bunch to $27.82 \mathrm{mg} / 100 \mathrm{~g}$ for sample palm bunch to $27.82 \mathrm{mg} / 100 \mathrm{~g}$ for the potash. Calcium is required for strong bone formation. Also potash had the highest calcium content, which was significantly $(\mathrm{p} \leq 0.05)$ different from others, thus showed that potash is composed of many minerals which is good for strong teeth and bone formation. Olusanya, (2008) potash which served as the control sample tend to be the best source of almost all the minerals evaluated, except for Phosphorus and Iron. Despite that, the plantain peels proved to be a very good source of those minerals except for Zinc. Plantain leaf is the best source of Phosphorus and Magnesium. In all the palm butch ash contained the least of all the minerals evaluated.

\section{Sensory Evaluation}

Presented in Table 2 were the results of the sensory evaluation of bread fruit samples cooked with the different softening agents. The sensory evaluation parameters evaluated were taste, colour,aroma,texture and overall acceptability. Sample A-bread fruit cooked with softening extracts from palm bunch; Sample-B bread fruit cooked with softening extracts from plantain peels, Sample-C bread fruit cooked with softening extract from plantain leaf and sample D cooked with softening extracts potash (Control).

Table.2 SENSORY EVALUATION OF BREAD OF BREAD FRUIT SAMPLES COOKED WITH DIFFERENT SOFTENING AGENTS.

\begin{tabular}{|c|c|c|c|c|c|}
\hline \multicolumn{6}{|c|}{ Parameters } \\
\hline Samples & Taste & Colour & Aroma & Texture & overall acceptability \\
\hline $\bar{A}$ & $4.44 \pm 0.00^{b}$ & $4.04 \pm 0.00^{d}$ & $4.04 \pm 0.00 \mathrm{c}$ & $8.4 \pm 0.00^{a}$ & $7.20 \pm 0.00^{c}$ \\
\hline B & $6.52 \pm 0.00^{\mathrm{a}}$ & $6.16 \pm 0.00^{c}$ & $6.24 \pm 0.00^{\mathrm{a}}$ & $8.1 \pm 0.00^{b}$ & $7.5 \pm 0.00^{\mathrm{a}}$ \\
\hline C & $6.44 \pm 0.00^{b}$ & $6.24 \pm 0.00^{b}$ & $6.20 \pm 0.00^{c}$ & $8.1 \pm 0.00^{b}$ & $7.30 \pm 0.00^{b}$ \\
\hline D & $6.72 \pm 0.00^{a}$ & $6.44 \pm 0.00^{\mathrm{a}}$ & $6.08 \pm 0.00^{b}$ & $8.2 \pm 0.00^{b}$ & $7.20 \pm 0 . \overline{0} 0 \mathrm{c}$ \\
\hline LSD & 0.01 & 0.01 & 0.02 & 0.01 & 0.02 \\
\hline Mean value & along the sam & e column hav & ing different & uperscripts a & are significantly different. $(\mathrm{p} \leq 0.05)$ \\
\hline
\end{tabular}

Mean Taste scores of the samples ranged from 4.44 for sample A to 6.72 for sample D. The sample $D$ (potash) had the highest value in terms of taste with the value 6.7, which was significantly $(\mathrm{p} \leq 0.05)$ higher than the mean scores of taste for the other samples. Traditionally bread fruit (ukwa)is cooked with potash as the softening agent. So the taste buds must be accustomed to such taste.

Colours of the samples evaluated by the panelist revealed that the sample D had the highest value in terms of colour. The colour of the samples ranged from 4.04 for sample A to 6.44 for sample $D$. The colour of sample $D$ was significantly $(p \leq 0.05)$ different when compared to sample A,B and C. The colour of sample A was the least acceptable the ash colour of the softening agent probably affected the colour of the food samples.

Aroma of the samples evaluate ranged from 4.04 for sample A to 6.24 for samples b. With aroma of the samples being significantly different $(\mathrm{p} \leq 0.05)$ from each other. Aroma of the 
samples was highest in sample B. this could be attributed to the flavor in the dried plantain peels.

The Texture sensory scores of the samples were high and close. The texture of the samples were 81.1 to 8.4 for sample A. Sample A texture scores was significantly $(\mathrm{p} \leq 0.05)$ different $(B \times C)$. The texture of food samples measures the degree of hardness or softness of a food product. Bread fruit samples when cooked with softening agents increases their degree of softness, thus increasing consumers acceptability because cooked bread fruit is expected to be very soft and tend to melt once in the mouth due to its soft texture.

Overall acceptability of the samples ranged from 7.20 for sample D to 7.50 for sample B. the sample B (plantain peel) from unripe plantain had the highest value of overall acceptability. The sample B was regarded as the best interms of overall acceptability due to its high values in terms of colour, taste, aroma and texture/mouth feel.

\section{CONCLUSION}

Softening agents used are food material by-product which are often discarded as waste and which has no use. The study revealed that unripe plantain peels are good source of minerals when incorporated in foods. Also among the softening agents used for cooking of bread fruit samples B (plantain peel had the highest value 7.5 in overall acceptability. The unripe plantain peels could be recycled into softening agents. Gradually the locals are introducing plantain peel preparations into their food menu. Use of the plantain materials- leaf and peel will add value $t$ the plantain crop. They also tend to be god sources of materials in addition to their softening capacity.

It is thus recommended that plantain peels regarded as waste should be harvested and converted as food softening agents rather than dumping it as waste material for manure and animal feed. Also food technologist should produce and package it as alternative food softening agents to potash, which tend to contain lead from environmental pollution.

Such softening agents could be produced on larger scale and marketed as ready to use without going through the rigors of production from scratch. Further work should be done to ensure the extraction such that the colour of the ash does not affect the food substance.

\section{References}

Adewale, A.O(2008) Quality attributes of hard to cook foods cooked Using agents in foods products Pakistan Journal.12:6-21

AOAC,(2006). Official Methods of Analysis, $18^{\text {th }}$ ed. Association of Analytical Chemist Washington DC.USA Daine, P.O(2004) Nutritional and sensory analysis of hard to cook foods of different legume varieties. Pakistan Journal of Nutrition 9:794-766

Ibeawuchi , I.I., Onweremadu, E.U. and Oti, N.N., (2006). Effects of poultry manure.

Olawole,P. (2000) Nutritional benefits of food softening agents in food Products Pakistan Journal.12:6-21.

Olusanya,J. (2008) Essentials of food Nutrition.on green .Apex books Limited Lagos. Pp 26-28.

Ploetz, R.C.; Kepler, A.K.; Daniells, J. and Nelson, S.C. (2007)."Banana and Plantain: An Overview with Emphasis on Pacific Island Cultivars". Species Profiles for Pacific Island Agroforestry.potash. International journal of Food Science. 12:8-9.

Quick guide potash.(2013).:http://www.geoalcali.com/en/quick-guide-to-potash 